\title{
Teachers' Perceptions on Factors Influence Adoption of Formative Assessment
}

\author{
Khalid Abdullah Alotaibi ${ }^{1}$ \\ ${ }^{1}$ College of Education, Prince Sattam Bin Abdulaziz University, Al Kharj, Saudi Arabia \\ Correspondence: Khalid Abdullah Alotaibi, Associate Professor, College of Education, Prince Sattam Bin \\ Abdulaziz University, Al Kharj, Saudi Arabia. E-mail: ka.alotaibi@psau.edu.sa
}

Received: October 1, 2018 Accepted: November 2, 2018 Online Published: December 30, 2018

doi:10.5539/jel.v8n1p74 URL: https://doi.org/10.5539/jel.v8n1p74

\begin{abstract}
Even though teachers has positive attitude towards formative assessment, their perceptions on factors influence the adoption of formative assessment is crucial to implement various assessment strategies effectively. Therefore, survey conducted on perceptions of primary school teachers in Riyadh province of Saudi Arabia regarding 14 selected factors. By stratified random sampling, data is gathered from the teachers of 15 schools located in the Riyadh province of Saudi Arabia. 210 fully completed questionnaires are received. Interrelated factors also discussed with a sample of 25 teachers. Teachers slightly agreed on all the given factors. However, significant perceptional differences between teachers groups are intervened that mainly attributed to male and female teachers, teachers who attended training and not attended, younger and elder teachers, less tenured and more tenured teachers, and the teachers of different subjects. This study results is noteworthy for understanding the perceptions of teachers on factors influence adoption of formative assessment in primary schools. Factors deliberated in this study are useful to the school management to address the challenges of teachers in formative assessment that would help to minimize the barriers for effective implementation of formative assessment.
\end{abstract}

Keywords: assessment strategies, constructive feedback, formative assessment, learning goals, pedagogy, self-learning

\section{Introduction}

Formative assessment would encourage self-learning and provide constructive feedback on students' performances (Bennett, 2011; Dix, 2017). Teachers believe that formative assessment has a profound impact on student motivation and achievement (Cauley \& McMillan, 2010). Even though teachers has positive attitude towards formative assessment practices (Young \& Jackman, 2014) they are less confident to implement formative assessment strategies (Leahy et al., 2005; Marshall \& Jane Drummond, 2006). The reason is some constraints of educational reforms, learning culture, curriculum changes, collaborative environment, accountability, stakeholders' perceptions, and the context of school environment that would influence teachers to adopt and implement the assessment strategies (Adamson, 2011; Verger et al., 2013; Hui et al., 2017).

However, these constraints would affect teachers from various domains namely external domain i.e. teachers' external sources of information and stimulus; personal domain i.e. teachers' attitude, beliefs, and knowledge; practice domain i.e. experimentation in profession; and consequences domain i.e. teaching outcomes (Komba, 2007). Thus, by review such domains, educational research has been established some possible factors that would influence teachers to adopt formative assessment. These factors are such as internal factors, resource-related factors, contextual factors, and other external factors like educational policies etc. (Antoniou \& James, 2014; Izci, 2016). Meanwhile, educators emphasize that these factors would cause a gap between theories and practice of formative assessment (Yeh, 2010).

In this context, teachers' perceptions on these factors is imperative (Alotaibi, 2016; Kyaruzi et al., 2018) not only to reduce the gap between the theories and practice but also to overcome the barriers in adopting formative assessment (Frunza, 2014). Different from earlier research, this paper focused on perceptions of primary school teachers in Riyadh province of Saudi Arabia and discussed their perceptional differences on given factors by socio-demographic profile. 


\subsection{Why Formative Assessment?}

Indeed, any type of assessment would reflect formative assessment that would help students to progress in lifelong learning as independent of teachers (Bell \& Cowie, 2001). However, Harlen and James (1997) made a distinction that summative assessment is for the overall learning achievements of students and formative assessment is on-going activities to advance the students' learning abilities. Though, the assessment information in both the cases has harmonious relationship and complementary (Black \& Wiliam, 1998), good summative continuous assessment would indicate students' grading that commonly denote as 'assessment of learning', on the other side good formative assessment support the judgment of teachers to progress the students' attainment levels in self-learning (Vaden-Goad, 2009).

Thus, formative assessment in literature denotes 'assessment for learning' (Black \& Wiliam, 2009) and aim to test the students' abilities, skills, and knowledge for achieving desired learning outcomes ((Dwyer, 2013; Clark, 2015). In fact, conception of assessment for learning makes learning process explicit by promoting learners' autonomy and control the assessment processes (Warwick et al., 2014). Whereas, formative assessment upsurge the students' motivation as well as self-regulation and compliment the new strategies in assessment practices (Missett et al., 2014). Therefore, formative assessment allow the teachers for deeper understanding of cognitive gaps in students learning and enable them to find new methods for effective teaching and minimize the learning gaps (Looney et al., 2017).

\section{Literature Review}

Yan and Cheng (2015) reveal that teachers' instrumental attitude, subjective norm, and self-efficacy would influence their intentions to conduct formative assessment, whereas their affective attitude and controllability will not influence them. Meanwhile, contextual factors has significant role in examining the formative assessment practices. However, Tan and Tan (2012) delimit that teachers' adoption of tasks in formative assessment would influence by students' abilities, students' motivation levels, course contents, teachers' involvement, assessment resources availability, manageability of assessment practices, and learning outcomes of the programmes. Ni Chroinin and Cosgrave (2012) unfold the challenges of teachers for the inclusion of formative assessment and outline the constraints such as the insufficient amount of time for planning formative assessment practices, difficulties in choosing the assessment strategies suitable for various students' abilities.

Some studies in different countries contextualized the factors that detain teachers in the adoption of formative assessment. For instance, Poole (2016) research on bilingual schools in Shanghai, China delineates the factors that restrain teachers to implement formative assessment. These factors are; resistance from teachers as well as students to implement innovative methods of formative assessment; notions of face among teachers as well as students about formative assessment methods; assessment materials emphasis on transmission of knowledge but not focused to improve skills and learning abilities of students. Martos-Garcia et al. (2017) inquiry at the schools of Basque and Valencia in Europe and find that students disapproved some assessments that would claim greater efforts to fulfill various standards in formative assessment.

However, Deneen and Brown (2016) disclose that teachers would influence by timely changes in the methods of formative assessment. In spite of this, Beatty et al. (2006) explain, teachers would succeed by adopting several methods and tactics to carryout formative assessment effectively. Subsequently, teachers would improve the classroom response system and achieve the different learning goals. Finally, teachers would frame new methods in formative assessment and collect the relevant feedback to have an insight on students' abilities (Wested.org, 2018). Despite, Minstrell et al. (2011) assert that teachers would influence the assessment practices of their colleagues and in this process; they follow formative assessment in a judicious manner and evade the misconceptions that largely based on lack of understanding of formative assessment practices. However, those teachers also confronted practical difficulties to design the assessment tools based on learners' thinking abilities. Further, Yin et al. (2008) find that teachers who follow the informal practices in assessments would witness the less positive results of formative assessment.

Likewise, Lai (2009) delineate that teachers' interim assessment during formative assessment would influence by factors such as assessment characteristics that did not encompass the detailed information for diagnosis of students' learning, and instructional practices that embarrass by unwillingness of using feedback results to find alternative pedagogies for improving students' learning. Some other factors are lack of subjectivity in the rubrics, relevant instructional methods to recover the students' learning outcomes. However, Safari and Rashidi (2015) signify that trainee as well as in-service teachers has impediments, concerns, and constraints to adopt formative assessment because of ideological, political, cultural transformations in the learning process. Clark (2011) also describe that teachers would have an impact of pedagogy that focused on cultural development of student and 
encapsulate by formative assessment techniques to evaluate the students' feedback within the cultural context.

Inclusively, the teachers' views on intervention of formative assessment (Meusen-Beekman et al., 2016) reveal that teachers declare formative assessment would increase their workload but not to the degree of perceive it as the burden or problem (Lopez-Pastor et al., 2013). However, others recognize that teachers' perceptions on formative assessment is most crucial for the effective implementation of formative assessment but not the excessive teaching workloads, size of the class, and policy decisions and reforms in education (Toh et al., 2006; Chin \& Wong, 2013). Some teachers expressed that lack of professional training on assessment would make them to compromise the inquiry based learning in formative assessment (Jaecheon, 2014; Polizzi et al., 2015).

\section{Problem Statement}

Formative assessment introduced at primary schools in Saudi Arabia since 1998 (Al Sadaawi, 2010; Alotabi, 2014). In the recent education reforms (Alnahdi, 2013; Hashmi et al., 2014), the Ministry of Education in Saudi Arabia has been insisted to implement formative assessment effectively at all levels of education. However, the resilience of teachers in the effective implementation of formative assessment is found (Gu \& Day, 2011) due to lack of time and more workload that clogged the teachers to put their attention on formative assessment practices (Al-Wassia et al., 2015). Other factors impeded teachers to adopt formative assessment mentioned by Alotaibi (2011) as following: larger class sizes, anxiety among students to get higher grades rather than improving their performances, mixed abilities in classroom, ambiguity at the guidelines. In this context, this study intends to discuss the perceptions of teachers in the primary schools in Saudi Arabia on likely factors that would inhibit the adoption of formative assessment.

\section{Methodology}

The aim of this study is to explore perceptions of teachers on factors influence to adopt formative assessment and to discuss the perceptional differences among teacher groups by socio-demographic profile. For the purpose, by review literature, 14 such factors selected as shown in table 9. To cover these factors, questionnaire was prepared. Responses collected on a five point Likert's scale from 'strongly agree' (5) to the 'strongly disagree' (1). Before the statements, the questionnaire has the details of socio-demographic profile of teachers i.e., gender, training status, age, teaching tenure, and subject of teaching.

Prior to start the main survey, a pilot study conducted with 54 teachers and the statements in the questionnaire finalized accordingly to elicit the exact responses of teachers. Finally, survey conducted by stratified random sampling method and 300 questionnaires circulated in 15 schools located in the Riyadh province. On an average, 20 teachers in each school received the questionnaire and total 210 returned as fully completed. The response rate was $70 \%$. The internal consistency of factors was $82 \%$.

Qualitative data also collected from 25 participants i.e. $11.90 \%$ of total sample. Interviews conducted with participants who agreed to discuss the interrelated factors that might influence the adoption of formative assessment. Excerpts of the interviews discussed in this paper.

However, to analyze the differences in perceptions, teachers segregated into groups. $61.2 \%$ male, $38.8 \%$ female; $23.8 \%$ in the age between $20-29$ years, $30.9 \%$ in $30-39$ years, $39.5 \%$ in $40-49$ years, and $5.8 \%$ in $50-59$ years. By teaching tenure, $33.8 \%$ completed 16 years, $27.6 \%$ completed $11-15$ years, $24.8 \%$ completed $6-10$ years, and $13.8 \%$ completed $1-5$ years of teaching. The distribution of the teachers by the subject they teach revealed that, $49.0 \%$ of them teach science, $20.5 \%$ teach biology, and $11.2 \%$ equally teach chemistry and general subjects, the remaining $8.1 \%$ teach physics. Of the total, $67.1 \%$ was attended training on formative assessment and the remaining i.e. $32.9 \%$ did not attended any training programmes.

Perceptional differences between teacher groups were analyzed by mean values, descriptive statistics, $t$-test, and ANOVA (one-way) F-test. Post hoc test conducted to identify the significant difference between teacher groups by age, teaching tenure, and subject in teaching.

\section{Study Results and Findings}

In table 1 , the mean value of study indicate that teachers slightly agreed on the given factors $(\mu=48.68,69.54 \%$, $\sigma=4.52)$. This mean value of study $(\mu)$ further compared with mean value of each group of study sample type $\left(\mu_{1}\right)$.

Table 1. Mean value and standard deviation of the study

\begin{tabular}{llllll}
\hline $\mathrm{N}$ & $\min$ & $\max$ & Mean $(\mu)$ & Mean $(\%)$ & $\mathrm{SD}$ \\
\hline 210 & 14 & 70 & 48.68 & 69.54 & 4.52 \\
\hline
\end{tabular}


As show in table 2 , female teachers slightly more receptive to the factors $\left(\mu_{1}=49.99, \sigma=4.52\right)$ than male teachers $\left(\mu_{1}=48.01, \sigma=4.39\right)$. While compared with study mean value $(\mu=48.68$, table 1$)$, male teachers was less agreed on the factors $\left(\mu_{1}<\mu\right.$ of table 1$)$ than female teachers $\left(\mu_{1}<\mu\right.$ of table 1$)$. The perceptional differences between male and female teachers was statistically significant $(t=3.05 ; p<.001)$.

Additionally, in table 2, teachers attended training on formative assessment practices was further agreed on factors $\left(\mu_{1}=49.99, \sigma=4.08\right)$ in comparison to teachers did not attend training on formative assessment $\left(\mu_{1}=46.00\right.$, $\sigma=4.20)$. Statistically, significant difference was found between these two groups of teachers $(t=6.60 ; p<.001)$. While compared with overall perceptions $(\mu=48.68$, table 1$)$, teachers did not attend training was less agreed upon factors $\left(\mu_{1}=46.00\right)$.

Table 2. Descriptive statistics by gender and training status

\begin{tabular}{lllllll}
\hline Sample type & Respondents & $n$ & Mean $\left(\mu_{1}\right)$ & SD & t-value & p-value \\
\hline \multirow{2}{*}{ Gender } & Male & 139 & 48.01 & 4.39 & \multirow{2}{*}{$3.05^{* *}$} & \multirow{2}{*}{0.000} \\
& Female & 71 & 49.99 & 4.52 & & \\
\hline \multirow{2}{*}{ Training on formative assessment } & Attended & 141 & 49.99 & 4.08 & \multirow{2}{*}{$6.60^{* *}$} & \multirow{2}{*}{0.000} \\
& Not attended & 69 & 46.00 & 4.20 & & \\
\hline
\end{tabular}

${ }^{* *} \alpha=0.01$.

In table 3 , teachers of age group 50-59 years was slightly agreed more $\left(\mu_{I}=51.00\right)$ in comparison to other age groups. Evidently, teachers of age 20-29 years was less agreed $\left(\mu_{I}=46.08\right)$ in comparison to overall perceptions of teachers $(\mu=48.68$, table 1). However, significant differences in the perceptions was acknowledged between the age groups of teachers $(F=9.43, p<.001)$. While compared with overall perceptions, younger teachers agreed less $\left(\mu_{1}=46.08\right.$ in 20-29 years) than elder teachers $\left(\mu_{1}=48.77\right.$ in 30-39 years; $\mu_{I}=49.84$ in 40-49 years; $\mu_{I}=51.00$ in 50-59 years). Proportionately, increase in the age of teachers resulted in more agreeability towards the factors.

Table 3. ANOVA results of age groups

\begin{tabular}{lllllllll}
\hline Age $(\mathrm{yrs})$ & $n$ & Mean $\left(\mu_{1}\right)$ & Groups & Sum of Squares & df & Mean Square & F-value & p-value \\
\hline $20-29$ & 50 & 46.08 & between groups & 515.44 & 3 & 171.81 & & \\
$30-39$ & 65 & 48.77 & within groups & 3754.18 & 206 & 18.22 & $9.43^{* *}$ & 0.000 \\
$40-49$ & 83 & 49.84 & Total & 4269.62 & 209 & & & \\
$50-59$ & 12 & 51.00 & & & & & & \\
$* * \alpha=0.01$.
\end{tabular}

Table 4 shows the post hoc test results between age groups of teachers such as 20-29 years, 30-39 years, 40-49 years, and 50-59 years. Considerable difference in the perceptions of teacher age groups was ensued mainly because of significant differences between 20-29 years with 30-39 years $(d=2.69, p<0.01), 40-49$ years $(d=3.76$, $p<0.01)$, and 50-59 years $(d=4.92, p<0.01)$. Clearly, great difference was seen between 20-29 years and 50-59 years. However, no significant difference was intervened because of elderly age groups (30 years and above). This would imply that teachers of elder ages fitted together in their views while agreed upon the given factors.

Table 4. Post hoc test results of age groups

\begin{tabular}{lllll}
\hline (I) Age (yrs.) & $(\mathrm{J})$ Age (yrs.) & Mean Difference $(d)(\mathrm{I}-\mathrm{J})$ & Std. Error & Sig. \\
\hline $20-29$ & $30-39$ & -2.69 & 0.80 & $0.00^{* *}$ \\
$20-29$ & $40-49$ & -3.76 & 0.76 & $0.00^{* *}$ \\
$20-29$ & $50-59$ & -4.92 & 1.37 & $0.00^{* *}$ \\
$30-39$ & $40-49$ & -1.07 & 0.71 & 0.51 \\
$30-39$ & $50-59$ & -2.23 & 1.34 & 0.43 \\
$40-49$ & $50-59$ & -1.16 & 1.32 & 0.86 \\
\hline
\end{tabular}

$* * \alpha=0.01$.

In table 5 , while compared with the overall perceptions $(\mu=48.68$, table 1$)$, less tenured teachers was less agreed (1-5 years, $\mu_{1}=46.66 ; 6-10$ years, $\left.\mu_{1}=47.94\right)$, whereas more tenured teachers was more slightly agreed (11-15 years, $\mu_{1}=48.72 ; 16 \&$ above years, $\left.\mu_{1}=50.01\right)$. However, the agreement levels of teachers increased 
proportionately to the increased work tenure and these perceptional differences between the work tenure groups of teachers was statistically significant $(F=4.70, p<.001)$.

Table 5. ANOVA results of work tenure groups

\begin{tabular}{lllllllll}
\hline Work tenure (yrs.) & $n$ & Mean $\left(\mu_{l}\right)$ & Groups & Sum of Squares & df & Mean Square & F-value & p-value \\
\hline $1-5$ & 29 & 46.66 & between groups & 273.67 & 3 & 91.22 & & \\
$6-10$ & 52 & 47.94 & within groups & 3995.95 & 206 & 19.40 & $4.70^{* *}$ & 0.000 \\
$11-15$ & 58 & 48.72 & Total & 4269.62 & 209 & & & \\
$16 \&$ above & 71 & 50.01 & & & & & & \\
\hline
\end{tabular}

$* * \alpha=0.01$.

As show in table 6, the substantial perceptional differences was prevalent among the teacher work tenure groups, because of significant contrast in the perceptions between less tenured and more tenured teacher groups i.e. 1-5 years and $16 \&$ above years $(d=3.36, p<0.05)$. Despite, the proximity in perceptions was resulted because of highly consistent views between $6-10$ years and $11-15$ years $(d=0.78, p>0.05)$. However, between other tenure groups also the views were coexisted regarding the given factors except between 1-5 years and $16 \&$ above years.

Table 6. Post hoc test results of work tenure groups

\begin{tabular}{lllll}
\hline (I) Tenure (yrs.) & $(\mathrm{J})$ Tenure $(\mathrm{yrs})$. & Mean Difference $(d)(\mathrm{I}-\mathrm{J})$ & Std. Error & Sig. \\
\hline $1-5$ & $6-10$ & -1.29 & 1.02 & 0.66 \\
$1-5$ & $11-15$ & -2.07 & 1.00 & 0.24 \\
$1-5$ & $16 \&$ above & -3.36 & 0.97 & $0.01^{*}$ \\
$6-10$ & $11-15$ years & -0.78 & 0.84 & 0.83 \\
$6-10$ & $16 \&$ above & -2.07 & 0.80 & 0.09 \\
$11-15$ & $16 \&$ above & -1.29 & 0.78 & 0.44 \\
\hline
\end{tabular}

$*_{\alpha}=0.05$.

As shows in table 7, the perceptions of teachers in different subjects were as follows. Biology $\left(\mu_{1}=45.51\right)$ and chemistry teachers $\left(\mu_{1}=46.79\right)$ was little pessimistic in their slight agreement levels in comparison to overall perceptions of teachers $(\mu=48.68$, table 1$)$. However, in the order of more agreement levels among the teachers of other subjects, general subject teachers was slightly more agreed $\left(\mu_{1}=50.96\right)$ followed by science teachers $\left(\mu_{1}=49.81\right)$ and physics teachers $\left(\mu_{1}=49.38\right)$. These variations in perceptions among the different subject groups of teachers was statistically significant $(F=11.46, p<.001)$.

Table 7. Variance in perceptions by subject taught

\begin{tabular}{|c|c|c|c|c|c|c|c|c|}
\hline Subject in teaching & $n$ & Mean $\left(\mu_{1}\right)$ & Groups & Sum of Squares & $\mathrm{df}$ & Mean Square & F-value & $\mathrm{p}$-value \\
\hline Biology & 43 & 45.51 & Between groups & 780.10 & 4 & 195.02 & & \\
\hline Chemistry & 24 & 46.79 & Within groups & 3489.53 & 205 & 17.02 & & \\
\hline Physics & 16 & 49.38 & Total & 4269.62 & 209 & & $11.46^{* *}$ & 0.000 \\
\hline Science & 103 & 49.81 & & & & & & \\
\hline General & 24 & 50.96 & & & & & & \\
\hline
\end{tabular}

Table 8 shows the immersion of great differences by subject groups that caused significant difference among the teachers. Out of ten different combinations of teacher subject groups, significant differences captivated between five combinations. Mainly, major dissimilarity immersed because of biology and general subject teachers $(d=5.45, p<0.01)$, and biology and science teachers $(d=4.29, p<0.01)$. In addition, these interpolations in perceptions was added with significant differences between chemistry and general subject teachers $(d=4.17$, $p<0.05)$, biology and physics $(d=3.86, p<0.05)$, and chemistry and science teachers $(d=3.01, p<0.04)$. 
Table 8. Post hoc test results of subject groups

\begin{tabular}{lllll}
\hline (I) Subject in teaching & $(\mathrm{J})$ Subject-taught & Mean Difference $(d)(\mathrm{I}-\mathrm{J})$ & Std. Error & Sig. \\
\hline Biology & Chemistry & -1.28 & 1.05 & 0.83 \\
Biology & Physics & -3.86 & 1.21 & $0.04^{*}$ \\
Biology & Science & -4.29 & 0.75 & $0.00^{* *}$ \\
Biology & General & -5.45 & 1.05 & $0.00^{* *}$ \\
Chemistry & Physics & -2.58 & 1.33 & 0.44 \\
Chemistry & Science & -3.01 & 0.94 & $0.04^{*}$ \\
Chemistry & General & -4.17 & 1.19 & $0.02^{*}$ \\
Physics & Science & -0.43 & 1.11 & 1.00 \\
Physics & general & -1.58 & 1.33 & 0.84 \\
Science & General & -1.15 & 0.94 & 0.82 \\
\hline
\end{tabular}

The perceptional sensitivities of respondents in each given factor shows in table 9. Teachers was positive and slightly agreed on all factors (Mean>3.00). This looked like they were consistent to respond on given factors. However, factor no.7 (Mean=3.69 \pm 1.27 min, rank 1) was set in the top rank as the major reason of the teachers to slightly agree. Factor no. $6\left(\right.$ mean $=3.33 \pm 1.38_{\min }$, rank 14) was engaged with the least rank to become minor reason of teachers to slightly agree. Factor no.10 (mean=3.49 $\pm 1.37_{\min }$, rank 7) and factor no. 1 (mean $=3.50 \pm 1.35_{\min }$, rank 6) was the midst factors as the perfect moderate reasons of the teachers to slightly agree. Overall, this study confine that teachers were familiar to the factors deliberated in this study that associated with adoption of formative assessment.

Table 9. Ranks of factors by mean values $(\mathrm{N}=210)$

\begin{tabular}{|c|c|c|c|c|}
\hline Rank & Factors influencing teachers in adoption of formative assessment. & Mean & SD & Factor no. \\
\hline 1 & $\begin{array}{l}\text { Does teachers' role and practices in formative assessment influence by the educational reforms of local and } \\
\text { national governments. }\end{array}$ & 3.69 & 1.27 & 7 \\
\hline 2 & $\begin{array}{l}\text { Does teachers' implementation of formative assessment influence by the policies and support of school } \\
\text { management. }\end{array}$ & 3.65 & 1.24 & 2 \\
\hline 3 & $\begin{array}{l}\text { Does teachers' importance to formative assessment influence by differences in students' abilities and } \\
\text { attitudes. }\end{array}$ & 3.63 & 1.42 & 5 \\
\hline 4 & $\begin{array}{l}\text { Does teachers' strategies in formative assessment influence by their professional experience and } \\
\text { participation in professional development programmes. }\end{array}$ & 3.58 & 1.23 & 11 \\
\hline 5 & $\begin{array}{l}\text { Does teachers' practices in formative assessment influence by the motivations from principals and peer } \\
\text { groups. }\end{array}$ & 3.56 & 1.24 & 13 \\
\hline 6 & $\begin{array}{l}\text { Does teachers' implementation of formative assessment influence by the curriculum materials such as } \\
\text { source books and syllabuses. }\end{array}$ & 3.50 & 1.35 & 1 \\
\hline 7 & $\begin{array}{l}\text { Does teachers' perceptions towards formative assessment practices influence by the curriculum and changes } \\
\text { in the curriculum. }\end{array}$ & 3.49 & 1.37 & 10 \\
\hline 8 & $\begin{array}{l}\text { Does teachers' effectiveness in formative assessment influence by the school working conditions (class } \\
\text { size, workload) and availability of assessment materials. }\end{array}$ & 3.45 & 1.40 & 14 \\
\hline 9 & $\begin{array}{l}\text { Does teachers' pedagogical knowledge in formative assessment influence by the students' strengths and } \\
\text { weaknesses. }\end{array}$ & 3.40 & 1.31 & 3 \\
\hline 10 & $\begin{array}{l}\text { Does teachers' attitude in formative assessment influence by the prevailing traditional learning and } \\
\text { assessment practices. }\end{array}$ & 3.39 & 1.45 & 12 \\
\hline 11 & $\begin{array}{l}\text { Does teachers' effectiveness in execution of formative assessment influence by learning culture in the } \\
\text { schools because of societal pressures from parents and school administration. }\end{array}$ & 3.39 & 1.37 & 9 \\
\hline 12 & $\begin{array}{l}\text { Does teachers' engagement of students in formative assessment influence by the beliefs or notions about } \\
\text { formative assessment in the society. }\end{array}$ & 3.37 & 1.41 & 4 \\
\hline 13 & $\begin{array}{l}\text { Does teachers' tolerance in formative assessment influence by the nature of flexibility or uncertainty in } \\
\text { assessment practices of formative assessment. }\end{array}$ & 3.35 & 1.38 & 8 \\
\hline 14 & $\begin{array}{l}\text { Does teachers' ideas or conceptions in formative assessment influence by the tensions of external } \\
\text { examinations and accountability. }\end{array}$ & 3.33 & 1.38 & 6 \\
\hline
\end{tabular}

\subsection{Results of Qualitative Data}

Teachers stated the interrelated factors that might influence adoption of formative assessment. Excerpts from interviews with 25 teachers are as follows. Teachers mentioned that they use formative assessment merely as the 
tool to measure the students' learning abilities and skills but not to achieve the intended learning outcomes. They opine that they generally treat formative assessment as counterproductive to grading systems and habituated to implement formative assessment as group activity but not to make the personalized intervention for achieving the learning goals of each individual student in the class. Teachers also stated that they have the customary of traditional learning culture in the schools that obligate them to follow the prevailing pedagogy and outdated assessment practices. As consequence, they told that they could not meet the requirements of rationale behind the recent developments in assessment. Majority of teachers suggested that students as well as parents and other stakeholders of primary education should involve during the debates on challenges of teachers in implementing formative assessment.

In the line with these viewpoints of teachers, Stiggins and DuFour (2009) expose that teachers would influence by the outcomes of sound decisions to implement new assessment methods. This would enable them to rely on collective expertise to assess the students' success in overall learning. Chen (2015), and Sezen-Barrie and Kelly (2017) disclose that teachers agree that they have the impact of inherent assessment culture that influence them to adopt formative assessment in a diverse work culture where teachers from different sociolinguistic backgrounds are working in the schools. However, Wiliam (2011) specified that lack of high involvement of teachers during the assessment practices and their lower motivation levels in milieu of teaching and feedback sessions are the main drawback of getting positive results from formative assessment.

To overcome the challenges of formative assessment, teachers mainly suggested that training programmes on the recent methods of assessment should conduct. This advice is in line with the argument of Yin et al. (2015) that teachers' self-efficacy and confidence would increase by involve them in continuous training. Moreover, Wylie and Lyon (2015) argue that teachers' fidelity, precision, and professional development would influence the quality of formative assessment.

Alternative suggestion of teachers is that, advantages of formative assessment should effectively communicate to the stakeholders of primary education in Saudi Arabia. While, some teachers expressed, Ministry of Education should focus on review the factors that would discourage teachers to adopt formative assessment. They emphasize that the Ministry of Education should address the concerns of teachers and school administrations to implement formative assessment effectively. These suggestions are in line with the Kemp and Scaife (2012) who advice that all stakeholders of primary education should realize the importance of formative assessment and they must encourage such assessments to benefit the students learning process.

\section{Discussion}

Teachers participated in this study was familiar with the given factors that would influence adoption of formative assessment. Though they slightly agreed upon given factors, as groups they had significant differences in their positive perceptions on the given factors. Mainly, these sizable high differences among them as groups step in because of highly expressive perceptional differences between different groups. This would imply that teachers' socio-demographic profile would influence adoption of formative assessment.

To some extent, female teachers was little agitated upon given factors than male teachers. Additionally, teachers attended training on formative assessment was little susceptible to given factors than teachers not attended training. This was an intermittent result as such the teachers attended training on formative assessment were supposed to be less prone to the factors that hinder formative assessment than teachers did not attend the professional development programmes (Nilsson, 2013). Moreover, teachers did not attend training would confront more difficulties in assessments in comparison to teachers attended training (Boote, 2016). However, during the interviews with teachers, they approved that they did not feel monotony by attended rigorous trainings on formative assessment; also, they had positive opinion on trainings conducted by the Ministry of Education on formative assessment.

However, younger teachers were little averse to given factors in comparison to elderly teachers. Proportionately, agreement levels among teachers increased by teachers' age. As implied, teachers of elderly ages would perceive more difficulties in formative assessment in comparison to younger teachers (Lampert, 2003; Furtak et al., 2016). On the other hand, teachers with higher level of agency in formative assessment were found to be inconsistent in their efforts to implement formative assessment due to their elderly age levels (Verberg et al., 2016) and accordingly they identify some suitable roles, designed the tasks, and managed their assessment practices (Wyatt \& Chapman-DeSousa, 2015).

Comparatively, teachers with tenure of below 5 years were little less disposed to the given factors and those tenured 16 years and above persuaded more about the given factors. It was obvious that the confidence levels of teachers would increase by more work experience (Sach, 2012) and the highly tenured teachers would increase 
their efforts to overcome the encounters in formative assessment and would serve as potential agents to promote formative assessment in education institutions (Cpr.indiana.edu, 2018).

Teachers of biology and chemistry subjects had fewer tendencies to agree upon given factors in comparison to the teachers of other subjects. This would imply that teachers of subjects that linked with laboratory practical work would have self-control over their assessment practices. Hence, teachers would regulate their efforts in assessments and this would make them not to perceive any hurdles of formative assessment (Keeley, 2013). However, it does not deny that, in the laboratory works of subjects like physics, teachers have several challenges due to the typical assessment approaches required in such courses (Nivalainen et al., 2010). Further, assessment in science laboratories was more task-oriented than fostering the laboratory learning through assessment practices (Stefanou \& Parkes, 2003). Therefore, irrespective of subjects in teaching, the general conception of formative assessment would propagate as the process of identifying cognitive competencies of students and assess their skills according to the underlying abilities of their thinking capacities (Ginsburg, 2009).

At the end, the study results indicate that teachers were more conscious to slightly agree in all the given factors and this outcome was similar to the study results of Vlachou et al. (2015) which identify that teachers are more reactive in conducting assessments rather than proactive to anticipate the challenges of assessment practices. However, authors inform that major complexities in assessments is always acknowledged by teachers due to the reasons of role ambiguities and confused expectations in formative assessment, and the devalued positions of teachers by extended their assessment duties in schools.

Finally, this study settled down with the results distinctive from earlier studies. For instance, Kelly et al. (2013) find teachers perceived the factors such as lack of enthusiasm in teachers about implementation of innovative methods in formative assessment, lack of strategies to improve the resilience among students in formative assessment, lack of perfection in teaching pedagogy with novel strategies of assessing learning, and lack of interconnectedness and more complex nature of formative assessment.

\section{Conclusion}

Even though teachers have positive attitudes towards formative assessment practices, their knowledge, fidelity and precision in the assessment practices would play a prominent role. This is not only to fill the gap between theories and practice of formative assessment, but also to overcome the barriers in adopting formative assessment practices and implement them effectively (Hondrich et al., 2015). Moreover, educational research mention, despite the teachers' assessment knowledge and pedagogical-content, teachers' assessment practices alone have positive relationship with student learning in formative assessment (Herman et al., 2015). However, educators identify several factors that would influence the teachers to adopt and implement formative assessment. Some of these factors reviewed and discussed in this paper. Moreover, this study contemplated that teachers' perceptions on such factors is crucial to adopt formative assessment. Therefore, surveyed the perceptions of 210 primary school teachers on 14 selected factors as exhibited and verified whether teachers agree on such factors or not. In addition, twenty-five teachers also interviewed to discuss the interrelated factors.

This study find teachers positively retorted to all the given factors. They are perceptible but not agreed to the greater extent. They slightly agreed more about the influence of educational reforms on adoption of formative assessment. This propensity to slightly agree upon other factors is similar but with a small decline in their agreement levels.

Mainly, they slightly agreed more about the influence of policies and support of school management, students' abilities and attitudes, professional experience and training, motivations from principals and peer groups. However, teachers are slightly less reluctant to agree on influence of external examinations and accountability, flexibility or uncertainty in formative assessment practices. Teachers are persistent to agree slightly about the influence of curriculum and the changes in the curriculum, curriculum materials and source books. In addition, their views are identical about the influence of traditional learning and assessment practices and learning culture in the schools.

However, significant differences exist between teacher groups by gender, age, training status, work tenure, and subjects in teaching. These ample disparities mainly arbitrated to male and female teachers; teachers attended training and not attended training, younger and elder teachers, less tenured and more tenured teachers, and teachers of different subjects.

During interviews, teachers revealed that they have misconceptions about formative assessment such as these assessments would only use to measure the students' skills, treating them as counterproductive to grading system, practicing them as a group activity. Teachers suggested that Ministry of Education should conduct more training 
programmes to the teachers on formative assessment. They added that stakeholders of formative assessment should participate in the debates on challenges of teachers in adaptation of formative assessment.

This study results is noteworthy for understanding the perceptions of teachers on factors influence adoption of formative assessment in primary schools. Factors deliberated in this study are useful to the school management to address the challenges of teachers in formative assessment that would help to minimize the barriers for effective implementation of formative assessment. Findings of this study would elaborate the readers' knowledge on perceptional differences among teachers on these kinds of factors by socio-demographic perspectives. Implications of this study are to comprehend the outlook of teachers' agreement levels towards the factors influence the adoption of formative assessment and what kind of socio-demographic characteristics made them considerably diverge in their views to differ significantly on such factors. Further researches could conduct on other similar factors that produce some more useful findings on this subject.

\section{References}

Adamson, B. (2011). Embedding Assessment for Learning. In R. Berry \& B. Adamson (Eds.), Assessment Reform in Education. Education in the Asia-Pacific Region: Issues, Concerns and Prospects, 14, 197-203. https://doi.org/10.1007/978-94-007-0729-0_14

Al Sadaawi, A. (2010). Saudi National Assessment of Educational Progress (SNAEP). International Journal of Education Policy and Leadership, 5(11), 1-12. https://doi.org/10.22230/ijepl.2010v5n11a202

Alnahdi, G. (2013). Educational Change in Saudi Arabia. Journal of International Education Research (JIER), 10(1), 1. https://doi.org/10.19030/jier.v10i1.8342

Alotabi, K. (2014). Student assessment strategies in Saudi Arabia: A case study of pre and post classroom practices. Literacy Information and Computer Education Journal (LICEJ), 3(1), 1758-1763. https://doi.org/10.20533/licej.2040.2589.2014.0234

Alotaibi, K. (2011). Investigation the questioning strategies and assessment practices in primary schools in science classes in response to the Saudi Arabian reform. PhD Thesis, La Trobe University, Australia.

Alotaibi, K. (2016). Classroom Assessment: Perception and Practices in Saudi Arabia. Germany: LAP Lambert Academic Publishing, pp. 145-161.

Al-Wassia, R., Hamed, O., Al-Wassia, H., Alafari, R., \& Jamjoom, R. (2015). Cultural challenges to implementation of formative assessment in Saudi Arabia: An exploratory study. Medical Teacher, 37(sup1), S9-S19. https://doi.org/10.3109/0142159X.2015.1006601

Antoniou, P., \& James, M. (2014). Exploring formative assessment in primary school classrooms: Developing a framework of actions and strategies. Educational Assessment, Evaluation and Accountability, 26(2), 153-176. https://doi.org/10.1007/s11092-013-9188-4

Beatty, I., Gerace, W., Leonard, W., \& Dufresne, R. (2006). Designing effective questions for classroom response system teaching. American Journal of Physics, 74(1), 31-39. https://doi.org/10.1119/1.2121753

Bell, B., \& Cowie, B. (2001). The characteristics of formative assessment in science education. Science Education, 85(5), 536. https://doi.org/10.1002/sce.1022

Bennett, R. (2011). Formative assessment: a critical review. Assessment in Education: Principles, Policy \& Practice, 18(1), 5-25. https://doi.org/10.1080/0969594X.2010.513678

Black, P., \& Wiliam, D. (1998). Assessment and Classroom Learning. Assessment in Education: Principles, Policy \& Practice, 5(1), 7-74. https://doi.org/10.1080/0969595980050102

Black, P., \& Wiliam, D. (2009). Developing the theory of formative assessment. Educational Assessment, Evaluation and Accountability, 21(1), 5-31. https://doi.org/10.1007/s11092-008-9068-5

Boote, D. (2006). Teachers' professional discretion and the curricula. Teachers and Teaching, 12(4), 461-478. https://doi.org/10.1080/13450600600644319

Cauley, K., \& McMillan, J. (2010). Formative Assessment Techniques to Support Student Motivation and Achievement. The Clearing House: A Journal of Educational Strategies, Issues and Ideas, 83(1), 1-6. https://doi.org/10.1080/00098650903267784

Chen, J. (2015). Formative assessment as a vehicle for changing classroom practice in a specific cultural context. Cultural Studies of Science Education, 10(3), 753-762. https://doi.org/10.1007/s11422-014-9599-7

Chin, E., \& Wong, P. (2013). Preparing Teachers: Highly Qualified to Do What? Editors' introduction. 
Education policy analysis archives, 21, 54. https://doi.org/10.14507/epaa.v21n54.2013

Clark, I. (2011). Formative assessment: Policy, perspectives and practice. Florida Journal of Educational Administration \& Policy, 4(2), 158-180.

Clark, I. (2015). Formative assessment: translating high-level curriculum principles into classroom practice. The Curriculum Journal, 26(1), 91-114. https://doi.org/10.1080/09585176.2014.990911

Cpr.indiana.edu. (2018). Relationship between Faculty Perceptions of Institutional Participation in Assessment and Faculty Practices of Assessment-Related Activities. Retrieved from http://cpr.indiana.edu/uploads/AERA11-Paper-FacultyAssessment-FINAL.pdf

Deneen, C., \& Brown, G. (2016). The impact of conceptions of assessment on assessment literacy in a teacher education program. Cogent Education, 3(1), 1-14. https://doi.org/10.1080/2331186X.2016.1225380

Dix, S. (2017). The effectiveness of formative assessment. Teachers and Curriculum, 6(1), 29-34. https://doi.org/10.15663/tandc.v6i1.202

Dwyer, C. (2013). The future of assessment (p. 7). New York: Routledge.

Frunza, V. (2014). Advantages and Barriers of Formative Assessment in the Teaching-learning Activity. Procedia - Social and Behavioral Sciences, 114, 452-455. https://doi.org/10.1016/j.sbspro.2013.12.728

Furtak, E., Kiemer, K., Circi, R., Swanson, R., de León, V., Morrison, D., \& Heredia, S. (2016). Teachers' formative assessment abilities and their relationship to student learning: findings from a four-year intervention study. Instructional Science, 44(3), 267-291. https://doi.org/10.1007/s11251-016-9371-3

Ginsburg, H. (2009). The Challenge of Formative Assessment in Mathematics Education: Children's Minds, Teachers' Minds. Human Development, 52(2), 109-128. https://doi.org/10.1159/000202729

Gu, Q., \& Day, C. (2011). Challenges to teacher resilience: conditions count. British Educational Research Journal, 1-23. https://doi.org/10.1080/01411926.2011.623152

Harlen, W., \& James, M. (1997). Assessment and Learning: differences and relationships between formative and summative assessment. Assessment in Education: Principles, Policy \& Practice, 4(3), 365-379. https://doi.org/10.1080/0969594970040304

Hashmi, M., Abdulghaffar, N., \& Edinat, I. (2014). Sustainability Commitment in Saudi Arabia and Need For Educational Reforms for the Jobs of the Future. International Business \& Economics Research Journal (IBER), 14(1), 47. https://doi.org/10.19030/iber.v14i1.9031

Herman, J., Osmundson, E., Dai, Y., Ringstaff, C., \& Timms, M. (2015). Investigating the dynamics of formative assessment: relationships between teacher knowledge, assessment practice and learning. Assessment in Education: Principles, Policy \& Practice, 22(3), 344-367. https://doi.org/10.1080/0969594X.2015.1006521

Hondrich, A., Hertel, S., Adl-Amini, K., \& Klieme, E. (2015). Implementing curriculum-embedded formative assessment in primary school science classrooms. Assessment in Education: Principles, Policy \& Practice, 23(3), 353-376. https://doi.org/10.1080/0969594X.2015.1049113

Hui, S., Brown, G., \& Chan, S. (2017). Assessment for learning and for accountability in classrooms: The experience of four Hong Kong primary school curriculum leaders. Asia Pacific Education Review, 18(1), 41-51. https://doi.org/10.1007/s12564-017-9469-6

Izci, K. (2016). Internal and External Factors Affecting Teachers' Adoption of Formative Assessment to Support Learning, World Academy of Science, Engineering and Technology, International Science Index 116. International Journal of Social, Behavioral, Educational, Economic, Business and Industrial Engineering, 10(8), 2800-2807.

Jaecheon, K. (2014). The Concept Map on Elementary School Teachers' Perceived Characteristics of Highly Qualified Teacher. The Journal of Korean Teacher Education, 31(3), 103-128. https://doi.org/10.24211/tjkte.2014.31.3.103

Keeley, P. (2013). Formative Assessment Probes: Is It Melting? Formative Assessment for Teacher Learning. Science and Children, 51(3), 1-3. https://doi.org/10.2505/4/sc13_051_03_26

Kelly, A., Gningue, S., \& Qian, G. (2013). First-Year Urban Mathematics and Science Middle School Teachers. Education and Urban Society, 47(2), 132-159. https://doi.org/10.1177/0013124513489147

Kemp, S., \& Scaife, J. (2012). Misunderstood and neglected? Diagnostic and formative assessment practices of 
$\begin{array}{lllll}\text { lecturers. Journal of Education for } & \text { Teaching, }\end{array}$ https://doi.org/10.1080/02607476.2012.656443

Komba, W. L. M. (2007). Teacher professional development in Tanzania: Perceptions and practices. Papers in Education and Development, 27, 1-27.

Kyaruzi, F., Strijbos, J., Ufer, S., \& Brown, G. (2018). Teacher AfL perceptions and feedback practices in mathematics education among secondary schools in Tanzania. Studies in Educational Evaluation, 59, 1-9. https://doi.org/10.1016/j.stueduc.2018.01.004

Lai, E. (2009). Interim assessment use in Iowa elementary schools. Ph.D. The University of Iowa, USA, p. 92. Retrieved from https://ir.uiowa.edu/cgi/viewcontent.cgi?article=1578\&context=etd

Lampert, M. (2003). Teaching problems and the problems of teaching. New Haven, Conn.: Yale University Press, p. 53.

Leahy, S., Lyon, C., Thompson, M., \& Wiliam, D. (2005). Classroom assessment minute by minute, day by day. Educational Leadership, 63(3), 18-24.

Looney, A., Cumming, J., van Der Kleij, F., \& Harris, K. (2017). Reconceptualising the role of teachers as assessors: teacher assessment identity. Assessment in Education: Principles, Policy \& Practice, 1-26.

Lopez-Pastor, V., Pintor, P., Muros, B., \& Webb, G. (2013). Formative assessment strategies and their effect on student performance and on student and tutor workload: the results of research projects undertaken in preparation for greater convergence of universities in Spain within the European Higher Education Area (EHEA). Journal of Further and Higher Education, 37(2), 163-180. https://doi.org/10.1080/0309877X.2011.644780

Marshall, B., \& Jane Drummond, M. (2006). How teachers engage with Assessment for Learning: lessons from the classroom. Research Papers in Education, 21(2), 133-149. https://doi.org/10.1080/02671520600615638

Martos-Garcia, D., Usabiaga, O., \& Valencia-Peris, A. (2017). Students' Perception on Formative and Shared Assessment: Connecting two Universities through the Blogosphere. Journal of New Approaches in Educational Research, 6(1), 64-70. https://doi.org/10.7821/naer.2017.1.194

Meusen-Beekman, K., Joosten-ten Brinke, D., \& Boshuizen, H. (2016). Effects of formative assessments to develop self-regulation among sixth grade students: Results from a randomized controlled intervention. Studies in Educational Evaluation, 51, 126-136. https://doi.org/10.1016/j.stueduc.2016.10.008

Minstrell, J., Anderson, R., \& Li, M. (2011). Building on Learner Thinking: A Framework for Assessment in Instruction. National Research Council Workshop on Successful Stem Education. Washington, DC: The National Academies Press, pp. 11-12. Retrieved from https://sites.nationalacademies.org/cs/groups/dbassesite/documents/webpage/dbasse_072645.pdf

Missett, T., Brunner, M., Callahan, C., Moon, T., \& Price Azano, A. (2014). Exploring Teacher Beliefs and Use of Acceleration, Ability Grouping, and Formative Assessment. Journal for the Education of the Gifted, 37(3), 245-268. https://doi.org/10.1177/0162353214541326

Ni Chroinin, D., \& Cosgrave, C. (2012). Implementing formative assessment in primary physical education: teacher perspectives and experiences. Physical Education \& Sport Pedagogy, 18(2), 219-233. https://doi.org/10.1080/17408989.2012.666787

Nilsson, P. (2013). What do we know and where do we go? Formative assessment in developing student teachers' professional learning of teaching science. Teachers and Teaching, 19(2), 188-201. https://doi.org/10.1080/13540602.2013.741838

Nivalainen, V., Asikainen, M., Sormunen, K., \& Hirvonen, P. (2010). Preservice and Inservice Teachers' Challenges in the Planning of Practical Work in Physics. Journal of Science Teacher Education, 21(4), 393-409. https://doi.org/10.1007/s10972-010-9186-z

Polizzi, S., Jaggernauth, J., Ray, H., Callahan, B., \& Rushton, G. (2015). Highly Qualified or Highly Unqualified? A Longitudinal Study of America's Public High School Biology Teachers. BioScience, 65(8), 812-821. https://doi.org/10.1093/biosci/biv093

Poole, A. (2016). "Complex teaching realities" and "deep rooted cultural traditions": Barriers to the implementation and internalisation of formative assessment in China.Cogent Education, 3(1), 1-14. https://doi.org/10.1080/2331186X.2016.1156242 
Sach, E. (2012). Teachers and testing: an investigation into teachers' perceptions of formative assessment. Educational Studies, 38(3), 261-276. https://doi.org/10.1080/03055698.2011.598684

Safari, P., \& Rashidi, N. (2015). Teacher education beyond transmission: Challenges and opportunities for Iranian teachers of English. Issues in Educational Research, 25(2), 187-203.

Sezen-Barrie, A., \& Kelly, G. (2017). From the teacher's eyes: facilitating teachers noticings on informal formative assessments (IFAs) and exploring the challenges to effective implementation. International Journal of Science Education, 39(2), 181-212. https://doi.org/10.1080/09500693.2016.1274921

Stefanou, C., \& Parkes, J. (2003). Effects of Classroom Assessment on Student Motivation in Fifth-Grade

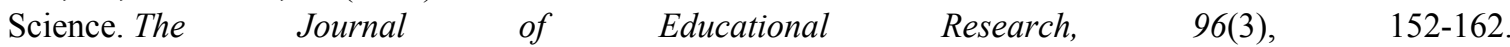
https://doi.org/10.1080/00220670309598803

Stiggins, R., \& DuFour, R. (2009). Maximizing the Power of Formative Assessments. Phi Delta Kappan, 90(9), 640-644. https://doi.org/10.1177/003172170909000907

Tan, P., \& Tan, A. (2012). Factors affecting primary science teachers' enactment of formative assessment: Reality and professional decision-making. In 2012 NARST Annual International Conference on Re-Imagining Research in 21st Century Science Education for a Diverse Global Community. The National Association for Research in Science Teaching (NARST), Reston, USA, pp.1-5.

Toh, K., Ho, B., Riley, J., \& Hoh, Y. (2006). Meeting the highly qualified teachers challenge. Educational Research for Policy and Practice, 5(3), 187-194. https://doi.org/10.1007/s10671-006-9008-4

Vaden-Goad, R. (2009). Leveraging Summative Assessment for Formative Purposes. College Teaching, 57(3), 153-155. https://doi.org/10.3200/CTCH.57.3.153-155

Verberg, C., Tigelaar, D., van Veen, K., \& Verloop, N. (2016). Teacher agency within the context of formative teacher assessment: an in-depth analysis. Educational Studies, 42(5), 534-552. https://doi.org/10.1080/03055698.2016.1231060

Verger, A., Altinyelken, H., \& Koning, M. ed., (2013). Global Managerial Education Reforms and Teachers: Emerging Policies, Controversies and Issues in Developing Contexts. Brussels: Education International, pp. 4-5.

Vlachou, A., Didaskalou, E., \& Kontofryou, M. (2015). Roles, duties and challenges of special/support teachers at secondary education: implications for promoting inclusive practices. European Journal of Special Needs Education, 30(4), 551-564. https://doi.org/10.1080/08856257.2015.1060073

Warwick, P., Shaw, S., \& Johnson, M. (2014). Assessment for Learning in International Contexts: exploring shared and divergent dimensions in teacher values and practices. The Curriculum Journal, 26(1), 39-69. https://doi.org/10.1080/09585176.2014.975732

Wested.org. (2018). Understanding Formative Assessment. Retrieved from https://www.wested.org/online_pubs/resource1307.pdf

Wiliam, D. (2011). What is assessment for learning? Studies in Educational Evaluation, 37(1), 3-14. https://doi.org/10.1016/j.stueduc.2011.03.001

Wyatt, T., \& Chapman-DeSousa, B. (2015). Teaching as Interaction: Challenges in Transitioning Teachers' Instruction to Small Groups. Early Childhood Education Journal, 45(1), 61-70. https://doi.org/10.1007/s10643-015-0758-6

Wylie, E., \& Lyon, C. (2015). The fidelity of formative assessment implementation: issues of breadth and quality. Assessment in Education: Principles, Policy \& Practice, 22(1), 140-160. https://doi.org/10.1080/0969594X.2014.990416

Yan, Z., \& Cheng, E. (2015). Primary teachers' attitudes, intentions and practices regarding formative assessment. Teacher and Teacher Education, 45, 128-136. https://doi.org/10.1016/j.tate.2014.10.002

Yeh, S. (2010). Understanding and addressing the achievement gap through individualized instruction and formative assessment. Assessment in Education: Principles, Policy \& Practice, 17(2), 169-182. https://doi.org/10.1080/09695941003694466

Yin, Y., Olson, J., Olson, M., Solvin, H., \& Brandon, P. (2015). Comparing Two Versions of Professional Development for Teachers Using Formative Assessment in Networked Mathematics Classrooms. Journal of Research on Technology in Education, 47(1), 41-70. https://doi.org/10.1080/15391523.2015.967560 
Yin, Y., Shavelson, R., Ayala, C., Ruiz-Primo, M., Brandon, P., Furtak, E., Tomita, M., \& Young, D. (2008). On the Impact of Formative Assessment on Student Motivation, Achievement, and Conceptual Change. Applied Measurement in Education, 21(4), 335-359. https://doi.org/10.1080/08957340802347845

Young, J., \& Jackman, M. (2014). Formative assessment in the Grenadian lower secondary school: teachers' perceptions, attitudes and practices. Assessment in Education: Principles, Policy \& Practice, 21(4), 398-411. https://doi.org/10.1080/0969594X.2014.919248

\section{Copyrights}

Copyright for this article is retained by the author, with first publication rights granted to the journal.

This is an open-access article distributed under the terms and conditions of the Creative Commons Attribution license (http://creativecommons.org/licenses/by/4.0/). 